\title{
陶磁器上絵具のシリカコーティングによる鉛溶出の抑制
}

\author{
堀内達郎・杉山豊彦・水野敬介* ・尾崎利彦・鈴木憲司 ・渡村信治・森 聰明 \\ 名古屋工業技術研究所, 462 名古屋市北区平手町 1-1 \\ *(有) 力ネ水水野絵具製造所, 507 多治見市上野町 1-60
}

\section{Suppression of Lead Leaching from Overglaze Decoration of Porcelain Tableware by the Sol-Gel Silica-Coating}

\author{
Tatsuro HORIUCHI, Toyohiko SUGIYAMA, Keisuke MIZUNO*, Toshihiko OSAKI, \\ Kenzi SUZUKI, Shinji TOMURA and Toshiaki MORI \\ National Industrial Research Institute of Nagoya, 1-1, Hirate-cho, Kita-ku, Nagoya-shi 462 \\ *Kanemizu Mizuno Color Works Co., Ltd., 1-60, Ueno-cho, Tajimi-shi 507
}

\begin{abstract}
In order to suppress the lead leaching from porcelain tableware, silica-coating on overglaze decoration by the sol-gel process was tried. The silica thin films were dense and it was suggested that the micropores larger than $0.36 \mathrm{~nm}$ (kinetic diameter of $\mathrm{N}_{2}$ molecule) did not exist. Only in the case a sol aged for a long time, micropore (pore diameter: $0.7 \mathrm{~nm}$ ) formation was observed. By the coating of the silica thin films which had no pores accessible for $\mathrm{N}_{2}$ molecule, lead leaching was suppressed to large extent. In the case of silica thin film with micropores of $0.7 \mathrm{~nm}$ in diameter, the amount of lead leached was almost the same as that of the specimen without coating. This tendency was due to the easiness of the diffusion of $\mathrm{Pb}^{2+}$ hydrated ion through the coating films depending on the relative size of $\mathrm{Pb}^{2+}$ hydrated ion $(0.46 \mathrm{~nm})$ and the pore diameter. [Received June 6, 1996; Accepted September 19, 1996]
\end{abstract}

Key-words : Overglaze color, Suppression of lead leaching, Silica-coating, Sol-gel process, Spin-coating, Micropore, $N_{2}$ adsorption

\section{1. 緒 言}

鉛を含んだ上絵具・釉薬を使用した陶磁器から酸性水溶液に より溶出する鉛は健康に害を及ぼす恐れがあるため，従来より 規制の対象となっているが，近年，米国において鉛溶出量の規 制值が更に厳しいものとなった．この規制を受けて各地の陶磁 器産地では, 鉛溶出に関して種々の対策が講じられるように なった.

主な対策としては，水蒸気雲囲気において焼成を行うと鉛溶 出量が大幅に減少するため1), 水蒸気吹き込み焼成法が普及し た. 現在では, 無鉛上絵具・無鉛釉薬の開発が進展してきてい る.

著者らは鉛溶出抑制への水蒸気雾囲気焼成の効果について検 討し ${ }^{2)}$, 水蒸気雾囲気において鉛等の元素の蒸発が促進される ことを見いだした．その結果，表面からの鉛の散逸によってシ リカに富んだ表面層が形成され，これが保護膜となって鉛溶出 が抑制されるものと考えた。

本研究では, 鉛を使用した上絵具の上にゾルゲル法により耐 酸性のシリカ薄膜の製膜を行い，鉛溶出を抑制することを試み た. ゾルゲル薄膜の化学的保護膜としての応用に関してジルコ ニアを含んだ膜で耐アルカリ性を向上させた報告があるが3),4), その数はあまり多くない. また，ゾルゲル法による酸化物薄膜 は多孔質であるが，このような多孔質膜を保護膜として用いた 場合には, 細孔中をある程度溶液が流通するものと予想され， 緻密な膜と同様の効果を得るためには，膜の微構造を制御する 必要があると考えられる.

本研究は，前述のような考えに基づいて，ゾルの合成条件な らびに薄膜の形成条件が膜の細孔構造に与える影響を検討し， 鉛溶出量との関係を明らかにすることを目的として行った.

\section{2. 実 験}

2.1 上絵具及びテストピース

タルク釉を施釉した直径 $6 \mathrm{~cm}$ の円形の磁器テストピースを
用意した．このテストピース上に上絵具を直径 $5 \mathrm{~cm}$ の転写 シールに加工したものを張り付けた. 上絵具には紺色の上絵具 （カネ水水野絵具製造所製，K-8800）を使用した. これは鉛フ リットを使用した製品である.この転写シールを張り付けたテ ストピースを電気炉中 $750^{\circ} \mathrm{C}$ で $30 \mathrm{~min}$, 空気䨌囲気中焼成し た.

\section{2 シリカゾルの合成}

アルコキシシランの酸加水分解によってシリカゾルを得た. 原料にはテトラエトキシシラン（以後TEOSと略す, $\mathrm{Si}\left(\mathrm{OC}_{2} \mathrm{H}_{5}\right)_{4}$, 関東化学製、有機合成用試薬）を用いた。ゾル の合成手順は次のとおりである.

TEOS $20.8 \mathrm{~g}(0.1 \mathrm{~mol})$ ビーカーに取り, 特級エタノー ル $10 \mathrm{ml}$ で希釈した. TEOSとエタノールの混合物をスター ラーでかくはんしながら $1 \mathrm{~N}$ 硝酸 $8 \mathrm{ml}\left(\mathrm{H}_{2} \mathrm{O}: 0.44 \mathrm{~mol}\right)$ を添 加し, TEOSを加水分解した. 硝酸を添加してから約 $15 \mathrm{~min}$ かくはんを続けた後, 加水分解したゾルをポリエチレン容器に 移して密栓し, $60^{\circ} \mathrm{C}$ に保った恒温槽中に静置して $2 \sim 4 \mathrm{~h}$ の所 定時間熟成した.

\section{3 シリカコーティング}

シリカコーティングはスピンコーティングにより行った. 2.2節で用意したシリカゾルを無希釈であるいは10〜30 $\mathrm{ml}$ の エタノールで希釈したものをパスッールピペットに約 $1 \mathrm{ml}$ と り, 回転基板に固定したテストピース上に流下してスピンコー トした。ゾルのシリカ含有量は 16 mass \% (無希釈), 14 mass\% (10 ml), 12 mass\% (20 ml), 10 mass\% (30 ml) であ る. 基板の回転速度は $1500,2250,3000$ 回転 $/ \mathrm{min}$ の三段階に 変化させた.ゾルを流下後, $5 \mathrm{~min}$ 回転を継続し, 室温で 15 $\min , 110^{\circ} \mathrm{C}$ で $15 \mathrm{~min}$ 乾燥した. 乾燥後, $300 \sim 750^{\circ} \mathrm{C}$ で $30 \mathrm{~min}$ 焼成し、コーティング膜をテストピース上に焼き付けた.

2.4 コーティング膜の厚さ

テストピースと同様の条件でスライドガラス上にコーティン グした膜の破断面を走査型電子顕微鏡（SEM ; 日立製作所製, 
S-2300）を用いて観察し, 膜厚を求めた.

\section{5 鉛溶出量の測定}

日本工業規格による方法5)で鉛溶出量を測定した．2.3節の ようにして得たシリカコーティングしたテストピースを $4 \%$ 酢酸 $100 \mathrm{ml}$ に浸し, $23^{\circ} \mathrm{C}$ で遮光して $24 \mathrm{~h}$ 放置し, 鉛を溶出さ せた，溶出後, テストピースを取り出し, 溶液中の鉛濃度を ゼーマン原子吸光光度計（日立製作所製）で定量した. 鉛溶出 量は上絵具の面積で除して, 上絵具加飾部分の単位面積当たり の溶出量として示した.

\section{6 コーティング膜の表面積・細孔分布}

スピンコーティングに使用した同じゾルから得た薄膜状ゲル の表面積ならびに細孔分布を測定した.ゾルをプラスチック フィルム上にごく薄く展開し, 室温でエタノールを蒸発させて

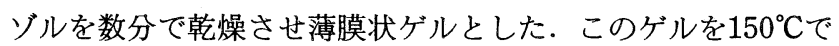
$15 \mathrm{~min}$ 乾燥した後に，テストピース焼成条件と同じ条件で熱 処理した. 熱処理後のゲルを用いてガス吸着量測定装置（日本 ベル製, Belsorp 36）で液体窒素温度における窒素吸着量を測 定した. 吸着データから Langmuir 法6)で比表面積を計算し た. また, $t$-plot ${ }^{7)}$ で細孔径, 細孔容積を求めた。窒素をほと

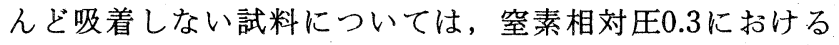
BET一点法で表面積を求めた。

\section{3. 結 果}

\section{1 ソルのシリカ含有量・基板回転速度と膜の品質}

ゾルゲル法によるシリカコーティングでは 1 回のコーティ ング操作で形成される膜が厚すぎると基板に密着せず，はく離 してしまう。そこでまず，透明な膜がはく離せずに形成される 条件を検討した.

図 1 にスピンコーティングしたシリカ膜の膜厚とゾルのシリ 力含有量ならびに基板の回転速度との関係を示す. この図に示

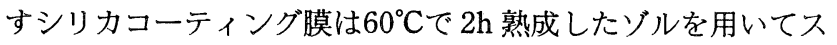
ピンコートした後, $500^{\circ} \mathrm{C} て ゙ 1 \mathrm{~h}$ 焼成して得た.ゾルの合成条 件や焼成温度を变えると膜厚も多少变化することが予想される が，ここでは膜を作製する条件を把握することが目的であるの で，それ以上の詳細な検討は行わなかった.

この図より基板の回転数が高いほど, なた, ゾルのシリカ濃 度が低いほど形成される膜の厚さは薄くなる傾向が認められ る. 目視観察によるはく離の有無を図の右側に併せて示した. 膜厚が約 $0.4 \mu \mathrm{m}$ 程度以下であるとはく離せずに膜が形成され た.

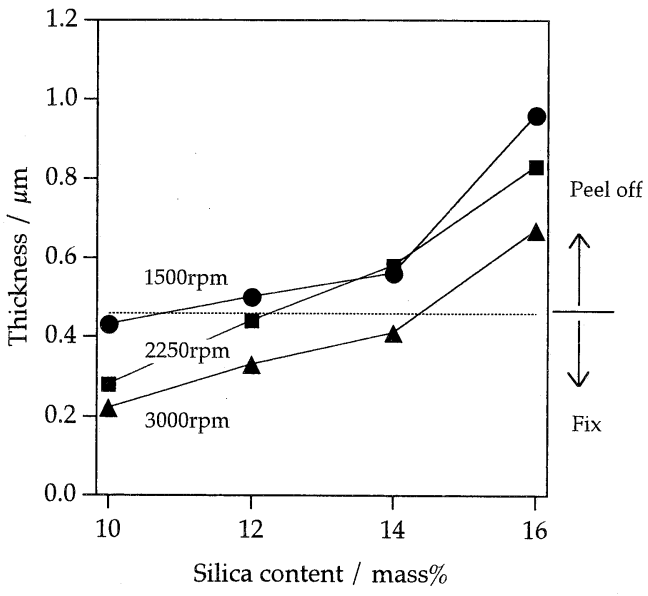

Fig. 1. Relation between the thickness of silica thin film and the silica content of the sol used for coating. Stage rotation rate:

$1500 \mathrm{rpm}, \mathbf{\square} 2250 \mathrm{rpm}$ and $\boldsymbol{\Delta} 3000 \mathrm{rpm}$.
3000 回転 $/ \mathrm{min}$ では透明膜を形成するのが容易である. しか し，溶出抑制のための保護膜としては厚いほうが望ましく，こ の回転数では膜厚が $0.2 \mu \mathrm{m}$ 程度とかなり薄くなる. 1500 回転/ $\min$ では透明膜を形成しうるゾルのシリカ濃度は 10 mass $\%$ 以 下と低いために希釈に用いる溶媒の量が増える.よって, 以降 の実験では透明膜が形成され，膜厚が比較的厚い回転数 $(2250$ 回転 $/ \mathrm{min}$ ）に固定し，シリカ濃度 12 mass \% と 10 mass\%のゾ ルを用いた。

\section{2 ソル調製条件・コーティング膜熱処理条件と鉛溶出量 の関係}

図 2 に鉛溶出量のゾル調製条件と熱処理温度による变化を示 す.シリカコーティングを行っていない試料からは約 $4.5 \mu \mathrm{g} /$ $\mathrm{cm}^{2}$ の鉛が溶出する.

シリカ含有量が 12 mass\%の場合（図 $2(a))$, 熟成時間が $0 \mathrm{~h}$ と $2 \mathrm{~h}$ の場合の鉛溶出量は, 熱処理温度に変わりなく 0.4 $1 \mu \mathrm{g} / \mathrm{cm}^{2}$ で無コーティングの場合の $1 / 10 \sim 1 / 5$ 程度であっ た.これに対して熟成時間が $4 \mathrm{~h}$ で熱処理温度が $300 \sim 500^{\circ} \mathrm{C}$ と 低い場合には，無コーティングとほほ同量の鉛が溶出した。熱

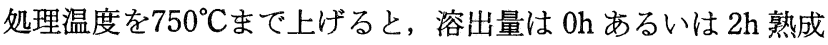
ゾルと同様の $0.5 \mu \mathrm{g} / \mathrm{cm}^{2}$ 程度まで減少した.

シリカ含有量が10 mass\%のゾルを用いた場合（図 $2(\mathrm{~b})$ ), $0 \mathrm{~h}$ あるいは $2 \mathrm{~h}$ 熟成したゾルでコーティングした試料からの鉛 溶出量は 12 mass\%の場合と同様で, 無コーティング試料の 1 / 10 程度であった．熟成時間が $4 \mathrm{~h}$ の場合は， 12 mass\%の場合
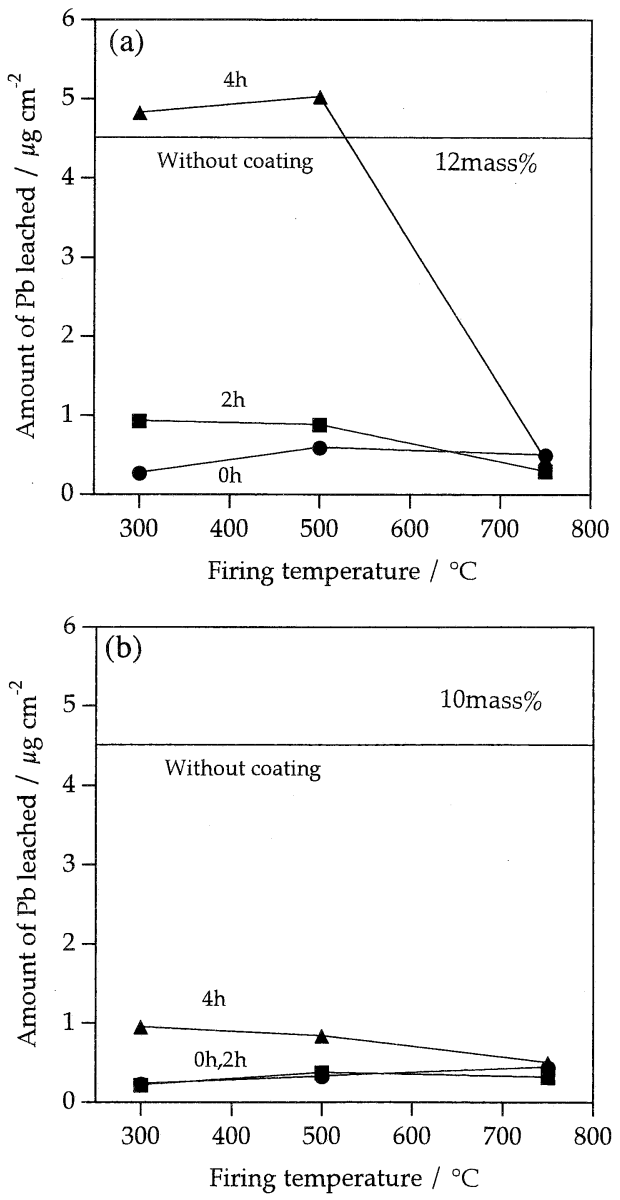

Fig. 2. Amount of lead leached from silica-coated specimens. (a) Silica content of the sol was 12 mass $\%$, Aging period: $0 \mathrm{~h}$, $2 \mathrm{~h}$ and $\boldsymbol{\Delta} 4 \mathrm{~h}$.

(b) Silica content of the sol was 10 mass $\%$, Aging period: $0 \mathrm{~h}$, $2 \mathrm{~h}$ and $\boldsymbol{\Delta} 4 \mathrm{~h}$. 
よりも低く $1 \mu \mathrm{g} / \mathrm{cm}^{2}$ 程度であった. 溶出量は, 熱処理温度の 上昇により減少して $0.5 \mu \mathrm{g} / \mathrm{cm}^{2}$ 程度となった。

\section{3 ゲル膜の窒素吸着等温線・細孔分布}

図 3 にゲル膜の比表面積の熱処理温度による变化を示す。シ リカ含有量 12 mass\%の場合（図 $3(\mathrm{a})$ ), 熟成時間が短いもの ではゲルの比表面積は加熱温度にかかわらず $1 \mathrm{~m}^{2} / \mathrm{g}$ 以下で
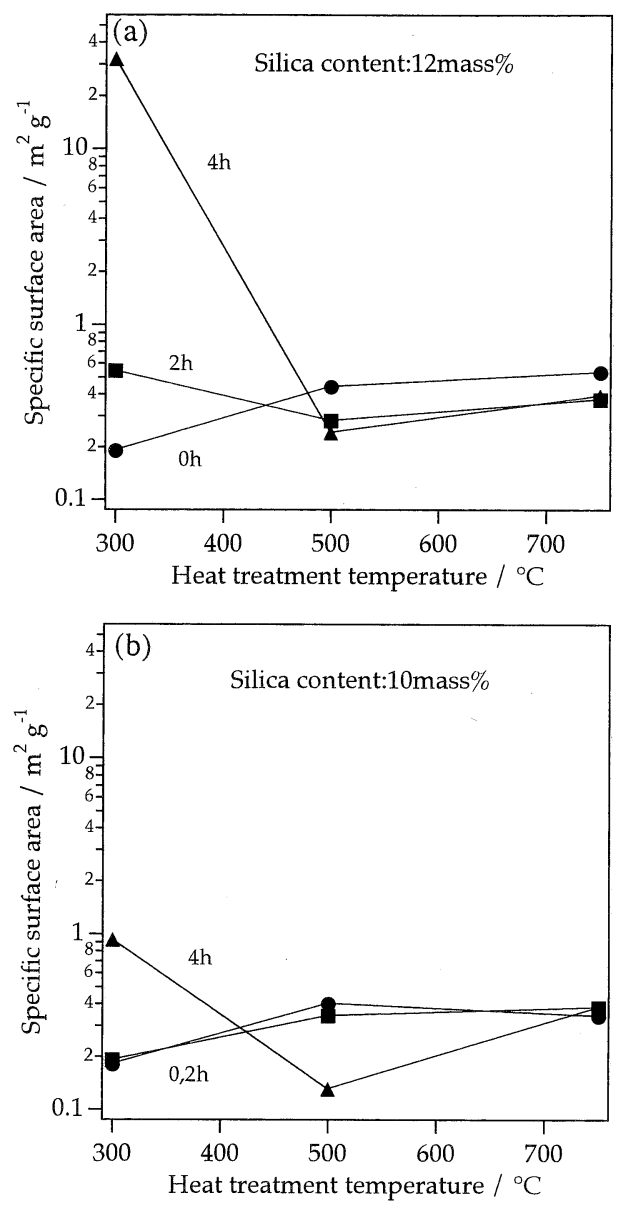

Fig. 3. Change in the specific surface area of thin film of silica gel with the heat treatment temperature. (a) Silica content of the sol was 12 mass $\%$, Aging period: $0 \mathrm{~h}, \mathbf{2} \mathrm{h}$ and $\boldsymbol{\Delta} 4 \mathrm{~h}$.

(b) Silica content of the sol was 10 mass\%, Aging period: $0 \mathrm{~h}$, $2 \mathrm{~h}$ and $\boldsymbol{\Delta} 4 \mathrm{~h}$.

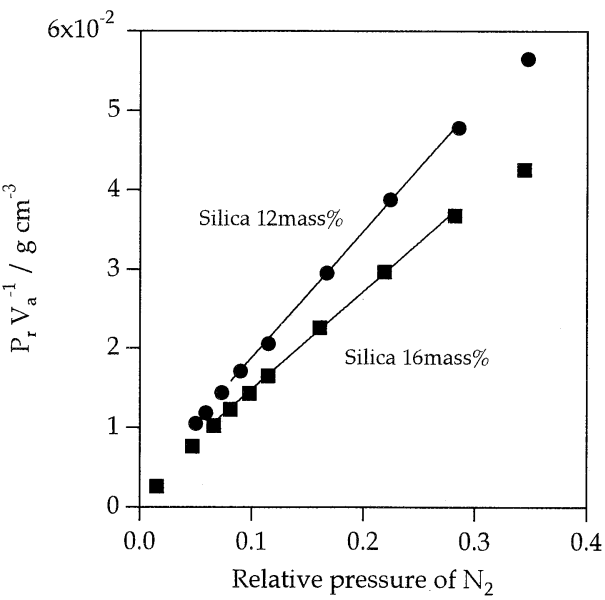

Fig. 4. Langmuir-plot of $\mathrm{N}_{2}$ adsorption data. Aging period was $4 \mathrm{~h}$ and heat treatment temperature was $300^{\circ} \mathrm{C}$. Silica content 12 mass $\%$, Silica content 16 mass $\%$.
あった。熟成時間が $4 \mathrm{~h}$ で加熱温度が $300^{\circ} \mathrm{C}$ の場合には Langmuir 型の吸着等温線が観察された. Langmuir-plot から比表 面積は $35 \mathrm{~m}^{2} / \mathrm{g}$ と求められた（図 4 ).このデータの $t$-plot を 行ったところ細孔径は $0.7 \mathrm{~nm}$ 程度, ミクロ孔細孔容積は 0.01 $\mathrm{ml} / \mathrm{g}$ であった．加熱温度を $500^{\circ} \mathrm{C}$ 以上に上げると焼結により 膜が緻密化するものと考えられ比表面積は $1 \mathrm{~m}^{2} / \mathrm{g}$ 以下に減少 した.

シリカ含有量 10 mass\%の場合（図 3 (b)）も比表面積の温 度变化は 12 mass\%の場合と類似しているが，4h 熟成ゾルから 得たゲルでも表面積は $1 \mathrm{~m}^{2} / \mathrm{g}$ 以下である点が異なる.

\section{1 膜の細孔構造}

\section{4. 考 察}

ゾルゲル法によって得られるシリカキセロゲルは通常多孔質 である. TEOS が酸性条件下で加水分解されて生じる粒子は, 不規則形状のフラクタルなケイ酸ネットワークであるとされて いる.このような粒子が時間とともに成長し，粒子が絡まり あって三次元構造を形成しゲル化する8)。このようなゲルを乾 燥させて得られるキセロゲルは概ね $1 \mathrm{~nm}$ から $3 \mathrm{~nm}$ 程度の細 孔径を有し, 比表面積は数百 $\mathrm{m}^{2} / \mathrm{g}$ ある ${ }^{9)}$.

本実験では窒素吸着測定のためのゲル膜はゾルの溶媒の自然 蒸発によって得ている. スピンコートした場合には遠心力が働 くので細孔構造が多少異なることも考えられる. しかし, 微細 な細孔を有するゲル構造が主に溶媒の毛細管力によって凝集し 収縮するとすれば, スピンコートでも自然乾燥させた場合で も，膜を堆積した時点での細孔構造に大きな違いはないと考え られる.

まず，シリカ含有量が 12 mass\%のゾルから得た膜について 検討する. 加熱温度 $300^{\circ} \mathrm{C}$ についてると，熟成時間が $0 \mathrm{~h}$ と $2 \mathrm{~h}$ の場合には窒素はほとんど吸着しない. 観察された表面積 は粒子の外表面積であると考えられる． $300^{\circ} \mathrm{C}$ 程度の熱処理で ゲルが完全に緻密化しているとは考えにくい，窒素が吸着しな いのは形成された細孔が窒素の動力学的分子径 $(0.36 \mathrm{~nm})$ よ りも狭い超ミクロ孔であるためと推測される. ゲル化以前に溶 媒を蒸発させると三次元構造が未発達であるため, 測定しうる 大きさの細孔が形成されないと考えられる，また，表面弾性波 によるコーティング膜の窒素吸着等温線測定結果においても, 熟成していないシリカゾルを用いてコーティングした薄膜には 窒素がほとんど吸着せず, 測定される表面積は膜の外表面積に 一致することが示されており10)，本実験の結果と整合性があ る.

熟成時間を $4 \mathrm{~h}$ まで延長すると $35 \mathrm{~m}^{2} / \mathrm{g}$ 程度の比表面積を示 すようになる. 気孔率は細孔容積から 0.02 と計算され，かなり 緻密な膜である. 細孔径は $0.74 \mathrm{~nm}$ で, 窒素分子径よりもやや 大きい程度の微細なものであるが，熟成により三次元構造があ る程度形成されることによって，測定可能な大きさまで細孔径 が大きくなったと推測される．本実験条件でゲル化が起こるの は $60^{\circ} \mathrm{C}$ 保持して $5 \mathrm{~h}$ 程度経過した時点であるので， $4 \mathrm{~h}$ の時 点でゲル化は起こらないものの三次元構造がある程度形成され ている可能性はある. $500^{\circ} \mathrm{C} て ゙$ 加熱することで，この細孔は焼 結して消滅し比表面積は $1 \mathrm{~m}^{2} / \mathrm{g}$ 以下となる。

シリカ含有量が 10 mass $\%$ の場合, 加熱温度が $300^{\circ} \mathrm{C}$ の試料 を比較すると, 熟成時間が $0 \mathrm{~h}$ と $2 \mathrm{~h}$ の場合には窒素をほとん ど吸着せず，シリカ含有量 12 mass\%と同様の結果となった。 熟成時間を $4 \mathrm{~h}$ としても, ゲルは窒素をほとんど吸着せず 12 mass\%の場合と異なっていた， $4 \mathrm{~h}$ 熟成した同じゾルでも, 希 釈の度合いが大きいと生成したゲルの細孔径が小さくなる.こ 
れは，熟成により形成されたシリカ粒子の絡なりあった三次元 構造が希釈により破壞されるためと推測される.

比較のため, シリカ含有量が16 mass\%（エタノールで希釈 していない）で $4 \mathrm{~h}$ 熟成したゾルを薄膜状ゲルとしたものの窒 素吸着量を測定したところ, Langmuir 型の吸着等温線を示し （図 4)，比表面積は $28 \mathrm{~m}^{2} / \mathrm{g}$ であった。 $t$-plotによる細孔径は $0.74 \mathrm{~nm}$, 細孔容積は $0.01 \mathrm{ml} / \mathrm{g}$ とシリカ含有量 12 mass\%ゾル と同様に測定しうる大きさの細孔を有することから，熟成によ り三次元構造が形成される途中の状態であると考えられる.こ のような熟成後のゾルに一定量以上のエタノールを加えて希釈 するとシリカ粒子の絡まりあった三次元構造が破壊されると考 えられる。

\section{2 細孔構造と鉛溶出量の関係}

鉛の溶出量とシリカゲル膜の細孔径の大きさの間には関連性 が認められる. 表面積が $1 \mathrm{~m}^{2} / \mathrm{g}$ 以下で窒素がほとんど吸着し ない超ミクロ孔を有する膜では鉛溶出量は $0.5 \mu \mathrm{g} / \mathrm{cm}^{2}$ 程度で あったが，細孔径が $0.7 \mathrm{~nm}$ の膜（シリカ $12 \mathrm{mass} \%$ で $4 \mathrm{~h}$ 熟成 し $300^{\circ} \mathrm{C}$ で熱処理したもの）では， $4 \mu \mathrm{g} / \mathrm{cm}^{2}$ の鉛が溶出した.

シリカ含有量 12 mass\%で $4 \mathrm{~h}$ 熟成し $500^{\circ} \mathrm{C}$ で熱処理した膜で

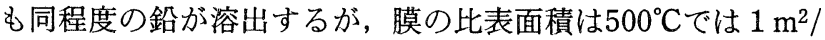
$\mathrm{g}$ 以下になっている．窒素吸着に用いたゲルは基板上にコー ティングされていないため，基板上にコーティングされた場合 よりも焼結しやすい状態にあるかもしれない，基板上での緻密 化の状態を直接測定する必要がある. $500^{\circ} \mathrm{C} て ゙$ 熱処理した試料

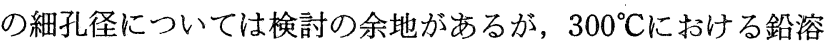
出量と膜の細孔径が大きいという傾向は，膜を通したイオンの 拡散しやすさと細孔径の間に関連性があることを示唆する。

水溶液中では金属イオンには水分子が配位し水和イオンとし て存在する．溶液中を移動する際にも水和イオンの形で移動す る. 水素イオンは水分子と結合してオキソニウムイオン $\left(\mathrm{H}_{3} \mathrm{O}^{+}\right)$として存在しその水和数は2.5 ${ }^{11)}, \mathrm{Pb}^{2+}$ の水和数は 5.7 あ゙あとされている12). $\mathrm{Pb}^{2+}$ 水和イオンの半径 (Stokes 半径）は0.23 nm と計算されている13)。この水和イオンは, 窒 素分子の入らない超ミクロ孔には侵入し得ない大きさである が，直径 $0.7 \mathrm{~nm}$ の細孔には侵入することが可能である。一 方, 水素イオンは, 水中ではオキソニウムイオンとして移動す るのではなく, 水素イオンが隣り合っている水分子の間を次々 に移動する14)。超ミクロ孔中でも同様に表面水酸基の間を移
動して容易に拡散するものと考えられる。

超ミクロ孔を有すると考えられる鉛溶出抑制効果の大きい コーティング層の場合, 水素イオンはコーティング層を拡散し て上絵具面まで到達するが，ガラス構造からはずれた $\mathrm{Pb}^{2+}$ イ オンが水和イオンとして拡散するとすれば，超ミクロ孔中の拡 散が障害となるために水溶液中に溶出する量が減少したと推測 される.

謝辞 本研究は中小企業庁国立機関技術開発研究事業「陶 磁器中鉛の溶出抑制のための新プロセッシング技術に関する研究 の一部として行われたものであり，関係者各位に感謝します。

\section{文献}

1) W. Roberts and W. H. Holman, Ceram. Ind., 91, 10-12 (1982).

2）堀内達郎，杉山豊彦，水野 薰，尾崎利彦，渡村信治，森 聰明, J. Ceram. Soc. Japan, 103, 1188-92 (1995).

3) D. Ganguli and D. Kundu, J. Mater. Sci. Lett., 3, 50304(1984).

4) N. Tohge, A. Matsuda and T. Minami, Chem. Express, 2, 185-94 (1987).

5) JIS S2400 (1991).

6) I. Langmuir, J. Am. Chem. Soc., 40, 1361 (1918)

7) J. H. de Boer, B. C. Lippens, B. G. Linsen, J. C. P. Broekhoff, A. Van den Heuvel and Th. J. Osinga, J. Colloid. Interfa. Sci., 21, 405-14(1966).

8) K. D. Keefer, "Science of Ceramic Chemical Processing", Ed. by L. L. Hench and D. R. Ulrich, John Wiley \& Sons (1986) pp. 131-39.

9) S. Wallace and L. L. Hench, "Science of Ceramic Chemical Processing", Ed. by L. L. Hench and D. R. Ulrich, John Wiley \& Sons (1986) pp. 149-55.

10) G. C. Frye, A. J. Ricco, S. J. Martin and C. J. Brinker, "Better Ceramics Through Chemistry III", Ed. by C. J. Brinker, D. E. Clark and D. R. Ulrich, Mater. Res. Soc., Pittsburgh (1989) pp. 349-54.

11) B. F. J. Vogin, P. S. Knapp, W. L. Flint, A. Anton, G. Highberger and E. R. Malinowski, J. Chem. Phys., 54, 17881 (1971)

12) T. J. Swift and W. G. Sayer, J. Chem. Phys., 44, 3567-74 (1966).

13）大瀧志, 田中元治, 舟橋重信, “溶液反応の化学”, 学会出 版センター (1977) p. 33

14）大瀧仁志, 田中元治, 舟橋重信, “溶液反応の化学”, 学会出 版センター (1977) p. 27 